\title{
INTERFERENCE OF THE DIFFERENT REALITIES WHEN WORKING WITH PSYCHODRAMA ONLINE AND ITS EFFECT ON THE PROTAGONIST AND THE GROUP
}

\author{
Galabina Tarashoeva1,* (iD
}

\begin{abstract}
In online psychodrama, with all its peculiarities and risks, is it possible to a complete therapeutic process take place, moved by the therapeutic factors: action catharsis, action insight, action learning, corrective emotional experience and reintegration of the new experience; the same as in psychodrama in therapeutic room? The focus is on possible effects and challenges of interference of different realities when working with psychodrama in the space of a virtual platform. Invasion of external reality in the individual space and reality of the auxiliary ego could influence the online group reality. The result can be a mixture of different times, spaces and realities, as well as the chance to unlock a deep process, catalyzing a personal work for the protagonist.
\end{abstract}

KEYWORDS: Psychodrama online; Therapeutic factors; Psychotherapy; Group therapy.

\section{INTERFERÊNCIA DAS DIFERENTES REALIDADES QUANDO SE TRABALHA COM PSICODRAMA ONLINE E SEU EFEITO SOBRE O PROTAGONISTA E O GRUPO}

\section{RESUMO}

No psicodrama online, com todas as suas peculiaridades e riscos, é possível realizar um processo terapêutico completo, executado pelos fatores terapêuticos: catarse de ação, insight de ação, aprendizagem de ação, experiência emocional corretiva e reintegração da nova experiência; o mesmo que em psicodrama na sala terapêutica? O foco está nos possíveis efeitos e desafios da interferência de diferentes realidades ao trabalhar com psicodrama no espaço de uma plataforma virtual. A invasão da realidade externa no espaço individual e na realidade do ego auxiliar poderia influenciar a realidade online do grupo. O resultado pode ser uma mistura de diferentes tempos, espaços e realidades, bem como a chance de desbloquear um processo profundo, catalisando um trabalho pessoal para o protagonista.

PALAVRAS-CHAVE: Psicodrama online; Fatores terapêuticos; Psicoterapia; Terapia de grupo.

\section{INTERFERENCIA DE LAS DIFERENTES REALIDADES A LA HORA DE TRABAJAR CON PSICODRAMA ONLINE Y SU EFECTO SOBRE EL PROTAGONISTA Y EL GRUPO}

\begin{abstract}
RESUMEN
¿En el psicodrama online es posible llevar a cabo un proceso terapéutico completo, realizado por los factores terapéuticos: catarsis de acción, insight de acción, aprendizaje de acción, experiencia emocional correctiva y reintegración de la nueva experiencia; el aunque sea en psicodrama en la sala terapéutica? El foco se centra en los posibles efectos y desafíos de la interferencia de diferentes realidades cuando se trabaja con psicodrama en el espacio de una plataforma virtual. La invasión de la realidad externa en el espacio individual y la realidad del ego auxiliar podría influir en la realidad grupal online. El resultado puede ser una mezcla de diferentes tiempos, espacios y realidades, así como la posibilidad de desbloquear un proceso profundo, catalizando un trabajo personal para el protagonista.
\end{abstract}

PALABRAS CLAVE: Psicodrama online; Factores terapéuticos; Psicoterapia; Terapia de grupo.

1.Psychodrama Center Orpheus ' $\mathrm{R}$ - Sofia, Bulgaria.

*Corresponding author: orpheuspsychodrama@gmail.com

Received: 29 Jul. 2021 | Accepted: 6 Dec. 2021

Section editor: Michael Wieser 


\section{INTRODUCTION}

In different places in the world, several years before the COVID-19 pandemic, psychodramatists started practices using psychodrama online for therapy or training. In 2016-2017, Viktor Semenov, Viktor Zaretsky and Zhanna Lurie conducted the project workshop named Psychodrama online: Opportunities, prospects and limitations (Semenov et al., 2020). The Russian Psychodrama Association has an online psychodrama section and started to organize annually conferences for online psychodrama. Hudgins (2017) started to offer the therapeutic spiral as action across the distance with telemedicine. Daniela Simmons created the term Tele'Drama, established the International Tele'Drama Institute (ITI) and started to offer online trainings and seminars (www.teledrama.org) and later on organizing big international online psychodrama conferences.

In the need imposed by the COVID-19 pandemic for the mass transition of psychodrama practice from real physical space in the therapeutic rooms to the virtual online space, many questions arose: How we will have a psychodramatic stage, one of the five main elements of our method, if we are not in the same physical space? Therefore, how we could direct psychodramatic action online if we don't have psychodrama stage? The big difference of psychodrama from other methods is that a person participates in it with their whole body, with their motility, with their kinesthetics, with all their senses, and not only with emotions and rationality. How, then, can there be psychodrama online when we interact with only part of our body in front of the camera? How the almost magical and amazing phenomenon of tele could manifests itself online? Isn't online psychodrama something untrue, artificial, superficial, some substitute for real psychodrama?

\section{A RESEARCH QUESTION}

For the flow of the therapeutic process and for the manifestation of the therapeutic factors of psychodrama the director has to provide protected safe space. In online psychodrama there is a risk the personal space of each participant to be open and the therapeutic process to be influenced by interference of different realities. The goal of the article is to answer the research question: In online psychodrama, with all its peculiarities and risks, is it possible to take place a complete therapeutic process, moved by the therapeutic factors: action catharsis, action insight, action learning, corrective emotional experience and reintegration of the new experience; the same as in psychodrama in therapeutic room?

The focus is on the possible effects and challenges of interference of different realities when working with psychodrama in the space of a virtual platform. The invasion of external reality in the individual space and reality of the auxiliary ego could influence the group online reality, which may affect the surplus reality on the virtual psychodrama stage and the inner psychic reality of the protagonist. The result can be a mixture of different times, spaces and realities, as well as the chance to unlock a deep process, catalyzing a personal work for the protagonist.

The author is looking for the answer to the question by describing and analyzing a case from her practice during the temporary transition of the psychodrama training in online format, due to the restrictions imposed in connection with the COVID-19 pandemic.

\section{THEORETICAL BACKGROUND}

We look at the therapeutic process as a counteracting to pathogenetic process, in which the therapeutic change is achieved under the influence of a set of therapeutic factors action catharsis, action insight, action learning, corrective emotional experience and reintegration of the new experience.

According to Kipper (2001), a prerequisite for effective psychodrama therapy is the ability in the therapy room to produce experiences that are of the same emotional and cognitive quality as those that occur naturally in life, activating the sensorimotor, kinesthetic, emotional and intellectual functions of the brain. This in psychodrama is achieved in a surplus reality, built on the psychodramatic stage, in which the boundaries of time fall away, and the events are reproduced and experienced as here and now, no matter how distant in real space, and in real time they have happened. The surplus reality (Kipper, 2001) arises from the temporary and protected removal of external and internal psychological boundaries. It is 
extremely important to remember that this removal of boundaries and inhabitation in surplus reality can happen only in the action space of the psychodramatic stage, in the therapeutic room, during the psychodramatic session. Returning to the group space during sharing restores the boundaries of real time and space and is a smooth transition, preparation for a return to the external reality of everyday life. According to J. Moreno and Z. Moreno (1959), the goal of psychodrama therapy is to make the client more spontaneous, while for David Kipper (2007) it is to facilitate the correction, reformulation and reorganization of the pool of significant client experiences.

Haim Weinberg (2021) discussing on challenges in online groups spoke about losing control of the setting. He clearly warns about the problem of losing the control of the therapist over the setting and other environmental conditions in which are the group members, organized by every one of them according to his wish. Weinberg (2016) draws attention to the risks of breaking the boundaries when switching group therapy online, which he named leaky container. He suggested that sometimes therapy (individual or group) can work well even when we have a leaky container.

\section{THE CONTEXT}

The COVID-19 pandemic forced many psychodramatists to look for adequate response to the totally new for the world situation, the skill named by J. Moreno and Z. Moreno (1959), to be spontaneous. The psychodramatists started intensive exchange of information and sharing of ideas and experiences via e-mail on how we could continue our work in the conditions of government's regulations for social isolation.

In our training center Orpheus, we agreed to use the virtual platform to practice psychodrama as close as possible to the one we know and direct in the therapeutic room. As well that there is no need of an artificial background to hide the real environment in which the participant is, no need for help of photos of empty chairs, benches and landscapes, models of chairs or various toys. With real chairs, if necessary to have some, but we all are present together in the real common internet space. When taking on a role, the auxiliary ego changes their name to the name of the role (allowing all the participants to use the rename function). In the virtual platform meeting, the group has two modes of operation, similar to those in the therapeutic room: a) analog of the Group is in a circle-all have cameras on in the circle; b) analogue of on the stage - only the protagonist, the director and the auxiliary egos are on the stage with cameras on, and the audience, the other participants have cameras off in the audience.

We decided not to name the work in therapeutic room face-to-face because in a virtual room we all are much more directly face-to-face. We also avoid in person, or in presence, to underling we are in person and in presence in both casesin the therapeutic room and in the virtual room. That is why we distinguish them with concretizing the space of working.

At the same time, we are clearly aware of the risks, not only of the unknown, but also of the loss of control over what is happening in the individual spaces of each of the participants and the impossibility of access to physical support and assistance, if necessary. In order to prevent the risks of violating the boundaries and confidentiality, we developed clear rules for working online and introduced the participants to them, we followed their observance as much as it is possibly.

In the training program in psychodrama, usually in Psychodrama Center Orpheus, we start the weekend with a verbal warming up, called measuring the pulse of the group, or in other groups named time connection. The first thing we do when the group starts is to find out what is the state of the group and every individual. The director of this session asks everybody how they are doing that day, if something important happened with their feelings and thoughts between the two meetings, and what are the expectations for this meeting - these give us important information for the state of the group.

During the meetings, conducted in the therapeutic room or in a virtual room, the trainees start to direct one another as trainee director of protagonist work, since the very beginning, with small and simple vignettes on structured exercises. When they start to feel more self-confident, they try to direct big and deep protagonist centered works, having clear in advance established rules for how they could ask help from the trainers, and how the trainers could intervene in the trainee director's directing. The case we will present and discuss about refers to the training in the first year, where the students are very enthusiastic to start to direct and at the same time careful and responsible enough, when somebody realizes that he/she is not skilled enough to continue the work, to ask the trainers, one of them to continue the directing. In such a case, 
the protagonist is asked to choose one of the trainers to continue the directing. In the whole session, the directing of the trainee director and the trainer is a subject of process analyses in one of the next sessions.

\section{METHODOLOGY}

The author is presenting a case of an online protagonist centered work during a training weekend, in which a small violation committed by a group member in his role as auxiliary ego unlocked a deep process in the protagonist and catalyzed an extremely important personal work for her.

The session started as directed by the trainee director under direct supervision of the two trainers, one of which is me, the author of this paper. Later on, I was asked to take over the directing. As usual, most of the students as well as the trainers take notes during the session in order to be able to be more precise in giving their feedback during the process analyses. The two trainers, as usual, analyzed the session in our staff meeting and, the day after, facilitated the process analyses with the whole group. In this case, we video recorded the session of process analysis with the whole group. This paper refers to the data collected from the written notes of the two trainers, with additions or corrections from the trainees' notes, the transcription of video record of process analysis session. Data were analyzed in the staff meeting with the co-trainer as well as in the process analysis session with the whole group. This allows the information in all written notes to be compared, corrected and the missed moments to be fulfilled.

Following the contract of confidentiality, the names of the protagonist and group members are fictional. Furthermore, the protagonist signed a written consent to allow the use of her story and even her name in a scientific article; however, I decided to change her name too. The protagonist also declared her consent to the whole group. In addition, she shared what has become a mission for her life: to speak freely and without secrets about adoption in society.

\section{PRESENTATION OF THE DATA: DESCRIPTION OF THE SESSION}

During the morning pulse measurement of the group, group member Lora shared that, in the last month, she felt held between two poles— she was either too rough, sharp and defended her position, after which she felt guilty, or she was too soft, yielding, frivolous, unbearable even for herself. She made it clear that she wants to explore this topic, and she was obviously warmed up for personal work. It was agreed that Lora would have a protagonist work after the lunch break, and would be directed by a trainee director Rali, chosen by her.

After the lunch break, before Lora to start her protagonist centered work, she said that during the lunch break she became very angry with her husband and mother-in-law. In the morning, she asked them to pay more attention to their younger son while she is in online meeting, because he is "the naughtiest of the three of them", and she was worried that he would go to the river with friends. She told them she had a feeling something wrong would happen to him. They ignored her warnings, and it turned out that the boy indeed had been in a risky situation on the river during her participation in the group. "Are these children only mine?" exclaimed Lora in the group, outraged. Besides, her husband had served lunch just for himself. Lora was almost ready to give up her personal work, she was so tense and angry. I reminded her of the morning topic for exploration, "How should I react, too rough or too soft, should I be angry or not?". Lora realized that the situation in her lunch break is just an illustration of the same feelings and inner doubts, and decided to continue her work.

Under the directing of her trainee director Rali, Lora chose auxiliary egos for the roles of herself, her husband, her mother-inlaw and their younger son, and in the course of the work she also chose an auxiliary ego for her anger. Each of them changed their names on their screens to the name of the role they took on. Everyone else was asked to turn off their cameras; the protagonist Lora, the auxiliary ego in the role of husband and the trainee director Rali were left on the stage with the cameras on.

In the interview with Lora's husband (represented by Lora in this role) we heard what Lora is for him and what he thinks about her, "I love her very much, I cannot live without her, we help each other"; "I am an earthlier, she is more spiritual, more impulsive"; "I make a lot of money to buy the best for them"; "Out of love for the children, she overdoes it, imagining things and suffers". 
In the course of the action, when the trainee director Rali invited Lora's anger to come on the stage, auxiliary ego Hari did not turn on his camera. Trainee director Rali waited for a while and asked him, "Are you here?". After not receiving an answer, she spontaneously told the protagonist, "Your anger is not here". Lora was invited to choose a new auxiliary ego for her anger, she gave him the words, "Children are looked after not only with money!", but in the next moment she turned to the group, "I am furious with all of you! Everyone is just waiting for the process to end".

The trainee director Rali was shocked, she realized that, in this new situation, she cannot continue the work if the protagonist has no trust to the group. She was not ready to direct the group dynamic work for solving this crisis situation for gaining back the trust of the protagonist to the group; and asked to be released from the role of director. We negotiated with the protagonist Lora who of the two trainers would take over the directing, and Lora chose me to direct her work.

I took over the directing and asked everyone in the group to turn on their cameras and everyone to be in their own role so that we could hear Lora's anger towards us. I invited Lora to express her anger towards who it is- the whole group, someone from the group, the trainers, as she feels.

Lora wanted to give up working, "it will pass, I will calm down". Both trainers did not accept this, telling her, "Lora, you have the right to be angry, it is not fair for you to give up!", "This can be useful for us; we will learn important things about ourselves!", "This is a theme of the group". Lora agreed to continue working.

The other trainer, suggested doubling of Lora said,"I feel rejected, abandoned by Hari" (the auxiliary ego who was supposed to be in the role of her anger). Lora confirmed it and continued, "When I have to, I'm here for everyone, and when I need someone to be here for me, they have something more important for them".

At my invitation to see a specific moment, Lora turned to the family. I insisted with her to look for someone else, from the group, including also me. Lora said that she prefers to keep it to herself, but I insisted that I prefer to know.

Lora, speaking to group member Krasi said, "Krasi, sorry, but this confidence of yours comes to me more, stiffens me".

There was nothing during this session and during the day that could explain this message from Lora to Krasi. As well as nothing to explain her next statement to the group, "The indifference... it is in the eyes of every one of you... I see it, you all want it all to end as soon as possible... Am I imagining? ... Everyone says that I am imagining, that I enter in some programs... I have very strong feelings... All these to end as soon as possible... All of it is unbearable...". Lora was speaking to everyone, very excited and tense, with pauses of emotionally saturated silence.

The protagonist was already with her hands on her face, her head bowed, her body trembling. Apparently, she was immersed somewhere in herself, in some other imaginary space, her voice became muffled, radiating deep pain.

The director asked Lora, when else did she have the same strong feelings? No answer followed.

On the next question of the director, "Where do they take you, these very strong feelings?", after some silence, Lora, answered, "Somewhere where it hurts a lot ... In the room where I am..."

The director, speaking very emphatically, "Lora, we are all here with you, for you!" I allowed myself to speak on behalf of the whole group, especially after her words about indifference of the group. I had to assure the protagonist that she is not alone, that we are all here with her, for her.

Both I and the group know that Lora is an adopted child, she has worked on the topic before in the group, and I felt that she is at a time in her earliest history. In the state of such deep regress, the protagonist needs extremely strong directing and support. When we are in the therapeutic room, and the protagonist is in such state of deep emotions and regress, I usually hold their shoulder and support their back with my hand. This risk of absence of just this feeling of support was shared as fear of participating in online psychodrama by several trainees: "How will I feel your arm on my shoulder when I need it?". The physical distance being in virtual room requires the feeling for support to be given mainly verbally, and this made the voice, sound and tone of speaking so important.

The director asked Lora, "How old are you?", which in Bulgarian language is "at how many years are you?" Lora answered after long silence, speaking as if seeing an action, we don't see, "I'm not years old... She goes out and slams the door behind her".

After asking, "Who is she?", and the answer, "Mom", the director asked Lora to enter in the role of her mom. We learned from Lora in this role, that her mom was under 16 years youngster when she gave birth to her. Pregnant from her first love, 
she had no support from her family and had to leave the baby in the maternity hospital. While in the role of her mother, Laura exclaimed, "Oh, my legs are cut off".

In the first scene (doing), auxiliary ego Krasi in the role of mom went out and slammed the door of the room (in Krisi's room, the door was right in front of her camera).

For the second scene (redoing), I instructed Krasi, as a mom, to take a pillow and hold it like a baby, while Lora, in the role of the little baby speaking to her, from her screen.

Lora, as newborn baby (renamed with the name by which she was recorded after the birth, different from the present one), in tears, managed to tell her mom what she needs, to cry out her pain, and after that to express her anger, "I cannot forgive you for leaving me while I slept, for not looking me in the eye, and for not saying goodbye to me ... You think I'm small and stupid and don't understand anything!"

After that, Lora in the role of her mom, also with a pillow, hugging it like a baby, met the needs of her child (another auxiliary ego, Agi, in the role of the baby), told her how strongly she loves her, how much she likes her and wants to be with her, how much she suffers that this is impossible.

Back in her role as little baby, Lora. heard words of love and admiration from her mom, presented by Krasi. Words of farewell and a wish for a better life than the one she can offer her, "I will never forget you; I will always love you and I will hope you will find me one day." Krasi, in the role of mom, telling these words to baby Lora, looking her in the eyes, deeply moved, was in real tears. In tears, like most of the group members, everyone behind her/his own small dark screen.

I instructed Krasi in the role of mom to go with her back ahead to the door and looking her baby in the eye as she goes out. Krasi, in the role of mom, carefully placed the baby (the pillow), stared at her for a long time, kissed her, and walked back to the door very slowly, without taking her eyes off her baby. When she went out, she spontaneously left the door slightly ajar.

Lora was calm, peaceful and very tired watching her mom going out. Her face was somehow slightly illuminated. The protagonist thanks sincerely and ask us to finish the work like this. The work was really long and that is why I did not insist on going back to the first scene in the present time, with the integrated new experience, as we usually are doing. Lora told us that she takes this new experience in her heart and does not need anything else.

The sharing was touching, with many tears, many memories of abandonment at an early age for many different reasons were awakened and shared.

In the sharing, Hari, who was chosen as an auxiliary ego for the role of anger, felt very guilty, explained that he is in his workplace, where no one was expected to come at that moment, but someone rang the doorbell and he had to go to see who it was. Lora told him that at the end it turned out to do her good and she is not angry at all with him. Hari also shared that he experienced very similar feelings in a period of his life when he also had been abandoned by his mother.

After her work Lora shared, "Just as mom thinks I'm small, stupid and incomprehensible, and doesn't tell me why she leaves me, doesn't look me in the eyes nor say goodbye to me, in the same way everyone in the family still thinks I'm small, stupid and misunderstanding, and no one takes my presentiments seriously. They tell me I'm getting into some kind of programs".

In the next morning, Lora shared, "I've always wondered why I suffer so much that I've been abandoned, when in fact it was for the better, I was raised with a lot of love and I'm not deprived of anything. And I see how bad I would be if I stayed with my biological mother, knowing where they are now (Lora has found her mother and her brothers and knows their conditions). Now I understand that it is because of the way she left me".

The next working weekend, Lora said that she talked to her biological mother, asked her about that moment, and her story largely coincides with what she experienced during her work.

\section{DISCUSSION}

Unexpected change in the individual space of one group member, chosen for an auxiliary ego, created a new reality here and now for him, which strongly influenced the group here and now virtual reality, evoking surprise and group crises. These individual and group changed realities, interfered the surplus reality, built on the virtual psychodramatic stage, in which the boundaries of time and space fall away once by definition, and second because of virtuality. All these took out the protagonist from the surplus 
reality of the scene with conversation with her husband and forced her to jump from it, back into the reality of the virtual here and now of the group.

The wave of unexpected change of reality starts from a daily individual level in the physical space, passes to a group-dynamic level in the virtual space, invades the virtual surplus reality on the psychodramatic stage and launches the protagonist into the reality of unbearable emotions and deep time jump. There was no past and present, everything merges, feelings overflow and pour out without distinguishing their recipients.

Interference of all these realities, traveling between the spaces and times, combined with hard feelings, sent our protagonist into extremely strong emotions from the very early traumatic experience. For few minutes she was in the same time in the two realities - in the group, speaking to the group members, and in the reality of emotions of the day of her abandonment in the maternity hospital. This emotional mixture of times and spaces at that moment looks like projection, in fact this was time jump or deep regression. The group had the chance to witness and to accompany Lora in her time trip to a newborn baby and back to our days.

In the situation of broken trust with the group, we have to stop the protagonist centered work and to do crisis intervention on group level to reestablish her trust. Without trusting the group, there is no chance for any protagonist work. Very precise doubling of protagonist's here and now feelings of "rejected, abandoned by Hari", gave us the permission to explore from when, where and whom started the original feelings of rejection and abandonment. Lora's feelings of indifference of the group which she sees "in the eyes of every one of you... I see it, you all want it all to end as soon as possible...", definitely was not provoked from somebody of group members. Invited to speak to the group here and now, Lora tries to go on family level, but I brought her back to group level, because the need was to regain her trust to the group. Then came another unprovoked feeling to the group member Krasi, who later was chosen for the role of her mom.

The feeling of abandonment in caring for the younger son and her presentiments ignored, reinforced by the husband serving lunch only to himself, culminated in Lora in the moment of absence of an auxiliary ego, when she needed him in the chosen role. Experiences of abandonment, loneliness and helplessness in the family and in the group reality, generated understandable anger, which she spreads to all in the group. The spark for the explosion of this anger was the words of the trainee director "Your anger is not here", which was a direct connection with the shared hesitation in the morning pulse and her shearing after lunch break-what to do with the anger?

This real life here and now anger touches on "very strong feelings" from the early childhood deep trauma of abandonment-an amalgam of feelings of rejection with indifference, loneliness, helplessness and anger of helplessness. The experience of indifference on the part of her mom, who left her, was transmitted and "seen" in the eyes of everyone in the group. Probably in the same way, Lora saw the group member Krasi with too much "confidence", "which stiffens me", as she experienced her mom going out and slamming the door behind her. Lora expresses to Krasi totally unprovoked anger, even before choosing her for the role of her mom.

The "very strong, unbearable feelings" of this very small baby for mom "who wants all these to end as soon as possible" because she "has something more important for her", and does not care that "I need someone to be here for me", was woken up by the absence of the auxiliary ego and spread to the whole group. As we know from J. Moreno and Z. Moreno (1959), the transfer in psychodrama usually is spread to the group members and auxiliary egos not to, or not only to the director.

After the session, Lora did not feel any indifference from the group.

Not by chance Lora, in the role of her too young mom, before leaving her baby, felt "oh, my legs are cut off". Psychodrama works on all levels of the person, including somatic, and experiences like that, happens in the case of deep role reversal.

In her role of newly born baby, Lora, crying deeply, experienced action catharses of her unbearable feelings to her momloneliness, rejection, abandonment, love and anger, and succeed to express her need for love and respect.

In the scene of redoing the separation with her mom, Lora had a chance to experience that crucial moment in a new way, fulfilling her basic needs of love, care and respect through corrective emotional experience. This new, healthy experience was reintegrated in her inner reality with the possibility of coexisting in parallel with the old, traumatic one, and to balance it. At the end of the psychodrama, the protagonist shared her action insight for her new understanding about the reasons for her feeling of not taken seriously by her relatives. In the next morning she shared her new understanding about the reasons for her big suffering for being an adopted child — the way it was done (action learning). 
In the described case of directing a protagonist centered work online, on the psychodrama stage on the screen of virtual platform, the protagonist and the auxiliary egos participated in psychodrama action, following the deep inner process of the protagonist. Role reversal and doubling techniques were implemented during the scene of doing in the way it happened, and in the scene of redoing in a new, less traumatic way. As in the therapy room, in the virtual room were produced experiences that are of the same emotional and cognitive quality as those that occur naturally in life, activating the sensorimotor, kinesthetic, emotional and intellectual functions of the brain (Kipper, 2001). The therapeutic change was achieved under the influence of a set of therapeutic factors action catharsis, action insight, action learning, (Moreno, Z., 1982) corrective emotional experience and reintegration of the new experience (Kipper, 2007).

We witnessed tele - the auxiliary ego for the role of her Anger was a group member who, had been also abandoned by his mother for a long period of his life, and experienced the similar feelings.

In the common online space, the transfer of feelings from the early childhood traumatic experience to the group threatened with a group conflict, which was met and worked out with exploring of the group process. Through doubling the feelings of the protagonist here and now was found $a$ key for going deep in the early childhood traumatic experience and the following personal work.

The "mistake" as this the absence of a group member in the role of auxiliary ego without this to be clear to the trainee director, trainers and the group is not possible to happen in working in a therapy room. It is possible only in the internet virtual room, when the group is working in the mode of operation analogue of on the stage, when only the protagonist, the director and the auxiliary egos are on the stage with cameras on, and the audience, the other participants, have cameras off-in the audience. In this case, the auxiliary ego was already chosen and waiting in the audience with the camera off to be invited on the stage when the protagonist needs him and then to turn on his camera. Accidentally, just in that moment, something happened in his own real space which did not allow him to open his camera and to enter in the surplus reality of the protagonist in the role of her anger. And nobody in the group could have known about this.

As Heloisa Fleury (personal communication, 2021) says: "There is no mistake in psychodrama, there are new paths to be explored".

\section{RESULTS}

The result of the analyses of the described case answers to the research question:

Online psychodrama, with all its peculiarities, risks and challenges in the virtual space, provides possibilities for a complete therapeutic process, the same as one, taking place in psychodrama directed in the therapy room. The manifestation of the therapeutic factors of psychodrama are the same - action catharses, action insight, action learning, corrective emotional experience and reintegration of the new experience. Psychodrama online facilitate the correction, reformulation and reorganization of the pool of significant client experiences (Kipper, 2007) as this is achieved by psychodrama in therapy room.

There are some other studies claiming no difference in therapeutic results between face-to-face and online care (Pieta \& Gomes, 2014; Thompson, 2016).

The private space of each participant, being out of the control of the director, brings risks of interference of many different realities, and mixing of experiencing times and spaces for the protagonist. The director has to provide clarity in every one moment about this, in which reality, space and time we are, and who, in which role is speaking. The director has to be very flexible and to move between individual and group level of working, if this is necessary. For the nature flow of the therapeutic process, the director has to have the skills to direct through following the protagonist in the reality she needs to go or jump.

\section{CONCLUSION}

The techniques, the process of working, the therapeutic processes in online psychodrama are the same as in the psychodrama at therapy room. Only the way of using the techniques could be different. Some unexpected events in the individuals' spaces, in addition to temporary and protected removal of external and internal psychological boundaries 
in surplus reality could lead to interference of different realities in the therapeutic process and challenges for the director, protagonist and the group. In online psychodrama it is even more important to remember that this removal of boundaries and inhabitation in surplus reality has to happen only in the action space of the virtual psychodrama stage, in the virtual therapy room, during the psychodrama session.

Sometimes the surprises coming from the leaky containers can lead to flowing of deeply buried tears and turn them into pearls.

\section{DATA AVAILABILITY STATEMENT}

All data sets in English were generated and analyzed in the current study. The data in Bulgarian language will be available upon request.

\section{FUNDING}

Not applicable.

\section{ACKNOWLEDGEMENTS}

With my deep gratitude to the protagonist for her trust and work, to the group members for their sincere involvement in the roles, and to my co-trainer for her creative team work!

\section{REFERENCES}

Hudgins, M. K. (2017). Action Across the Distance with Telemedicine: The Therapeutic Spiral Model to Treat Trauma-Online. In S. L. Brooke (Ed.), Combining the creative therapies with technology: Using social media and online counseling to treat clients. Springfield: Charles C. Thomas.

Kipper, D. A. (2001). Surplus reality and the experiential reintegration model in psychodrama. International Journal of Action Methods: Psychodrama, Skill Training, and Role Playing, 53(3-4), 137-152.

Kipper, D. A. (2007). Reformulating psychodrama as an experiential reintegration action therapy (ERAT) the corrective emotional approach. In B. Clark, J. Burmeister \& M. Maciel (Eds.), Psychodrama: Advances in theory and practice (pp. 41-52). London: Routledge.

Moreno J. L., \& Moreno Z. T. (1959). Psychodrama: Second volume: Foundations of psychotherapy. Beacon House.

Moreno, Z. T. (1982). Psychodramatic rules, techniques and adjunctive methods. Mental Health Resources.

Pieta, M. A. M., \& Gomes, W. B. (2014). Psicoterapia pela Internet: viável ou inviável? Psicologia: Ciência e Profissão, 34(1), 18-31. https://doi.org/10.1590/S1414-98932014000100003

Semenov, V., Zaretsky, V., \& Lurie, Z. (2020). Psychodrama online: Opportunities, prospects and limitations. Sociedade Portuguesa Psicodrama Psicanalítico.

Thompson, R. B. (2016). Psychology at a distance: Examining the efficacy of online therapy [Undergraduate thesis, Portland State University]. PDXScholar. https://doi.org/10.15760/honors.292

Weinberg, H. (2016) Impossible groups that flourish in leaking containers': Challenging group analytic theory? Group Analysis, 49(4), 330-349. https://doi.org/10.1177/0533316416667326

Weinberg, H. (2021). Obstacles, challenges, and benefits of online group psychotherapy. The American Journal of Psychotherapy, 74(2), 83-88. https://doi.org/10.1176/appi.psychotherapy.20200034 